\title{
Impact of Curcumin on Nucleic Acids in Diethanolamine Induced Toxicity in Mus musculus
}

\author{
Hetal Doctor, Sanman Samova*, R.J.Verma \\ Department of Zoology, University School of Sciences, Gujarat University, Ahmedabad-380009, India. \\ *Corresponding author's E-mail: samova.sanman@gmail.com
}

Received: 25-11-2020; Revised: 06-07-2021; Accepted: 18-07-2021; Published on: 15-08-2021. \begin{abstract}
Tremendous hike in the use of chemicals in every consumables worldwide, led researchers to investigate the effects of various products and their ingredients that are being used in routine. Diethanolamine (DEA) is one such organic compound used in various industries and several personal care products that are being used daily. To evaluate DEA toxicity on nucleic acid content, Swiss strain male albino mice were chosen as animal model for in vivo experiments. Mice were exposed to DEA (110, 165, $330 \mathrm{mg} / \mathrm{kg}$ body weight/day) for 30 days. Animals were sorted into nine different groups, each containing 10 animals per group. In untreated control groups of animals no significant changes in nucleic acid content were noted whereas in DEA exposed animals, nucleic acid content decreased significantly $(p<0.05)$ in a dose-dependent manner. However, more decrease were noted in high dose $(330 \mathrm{mg} / \mathrm{kg}$ body weight/day) exposed animals as compared to other groups of animals. For the mitigation of the toxicity generated by DEA, curcumin, a miraculous antioxidant, which is an active component of turmeric was used. Curcumin $(10,20,30 \mathrm{mg} / \mathrm{kg}$ body weight/day) was orally administered for 30 days along with the high dose of DEA. After completion of treatment, animals were humanly sacrificed and liver was quickly isolated for further biochemical evaluations. In animals exposed to curcumin for 30 days the nucleic acid content increased significantly $(p<0.05)$ as compared to DEA-HD treated groups of animals. The effect was dose-dependent. The ameliorative effect of curcumin might be due to its high antioxidant potency.
\end{abstract}

Keywords: Diethanolamine, nucleic acid, curcumin, liver, amelioration.

QUICK RESPONSE CODE $\rightarrow$

DOI:

10.47583/ijpsrr.2021.v69i02.004

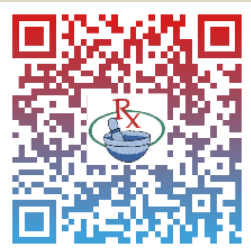

DOI link: http://dx.doi.org/10.47583/ijpsrr.2021.v69i02.004

\section{INTRODUCTION}

non (1983) described that diethanolamine often abbreviated as DEA is an organic compound. It is highly reactive as it comprises two functional groups alcohol and amine. Some investigators noted that diethanolamine is used in pharmaceutical industries as a $\mathrm{pH}$ stabilizer, in outer covering of capsules as plasticizer ${ }^{2}$. It is also used in cosmetics as an emulsifier to provide smooth leathery texture to products such as shampoos, lotions, and hand washes ${ }^{2}$.

It has been described by Hewlings and Kalman (2017) that though modern medicines have become the forefront of clinical practice nowadays, natural plant products continue to be used as remedies in alternative medicine throughout the world ${ }^{6}$. Phytochemicals have been used as the basis of some medical treatments in humans. One such phytochemical is curcumin. It has been noted (Kocaadam and Sanlier, 2017) that curcumin is an active component of turmeric. Curcuma longa plant roots are the only source of curcumin. It is a marvel molecule possessing numerous antioxidant properties ${ }^{7}$.

\section{STUDY DESIGN}

\section{Experimental animals}

In this study, healthy Swiss strain male albino mice weighing 30-35g were obtained from Cadila Research Centre, Ahmedabad, India. Animals were housed in an air - conditioned room at a temperature of $25 \pm 2^{\circ} \mathrm{C}$ and 50 $55 \%$ relative humidity with a $12 \mathrm{~h}$ light/dark cycle throughout the experiment. Animals were fed with certified pelleted rodent feed supplied by Amrut Feeds, Pranav Agro Industries Ltd., Pune, India and potable water. Mice were acclimatized to the laboratory conditions for two weeks prior to the treatments. All the experimental protocols were approved by the Committee for the Purpose of Control and Supervision of Experiment on Animals (Reg- 167/GO/ReBi/S/99CPCSEA), New Delhi, India. Animals were handled according to the guidelines published by Indian National Science Academy, New Delhi, India (1991). Well nourished, adult Swiss strain albino mice were chosen and sorted into nine groups of 10 mice each.

\section{Dose selection}

On the basis of LD50 value, different doses of DEA was selected. DEA-treated groups of animals were administered with three different doses of DEA, which is $1 / 10^{\text {th }}, 1 / 20^{\text {th }}$ and $1 / 30^{\text {th }}$ of $\operatorname{LD}_{50}(330,165$ and $110 \mathrm{mg} / \mathrm{kg}$ bw/day respectively) for 30 days. For ameliorative studies, three different doses of curcumin $(10,20$ and $30 \mathrm{mg} / \mathrm{kg}$ bw/day).

Swiss strain healthy male albino mice were used for the present study. Ninety animals were randomly divided into 
nine experimental groups and caged separately. Each group contained 10 mice. All experimental animals were subjected to overnight fasting prior to the treatment. Animals of group one was maintained without any treatment (Untreated control). Whereas second group (vehicle control) of animals received olive oil $(0.2$ $\mathrm{ml} /$ animal/day). Curcumin was dissolved in olive oil hence it was used as vehicle control. Third group (antidote control) animals received $30 \mathrm{mg} / \mathrm{kg}$ body weight/day curcumin. Fourth, fifth and sixth group of animals received 110, 165 and $330 \mathrm{mg} / \mathrm{kg}$ body weight/day of DEA respectively. In addition to high dose of DEA $(330 \mathrm{mg} / \mathrm{kg}$ bw/animal/day), animals of group seven, eight and nine received 10, 20 and $30 \mathrm{mg} / \mathrm{kg}$ body weight/day curcumin. All doses were orally administered using stomach tube for the duration of 30 days. On completion of treatment animals were humanely sacrificed. Liver was immediately isolated, blotted free of blood and used for further analysis.

\section{Chemicals}

Analytical grade diethanolamine and curcumin were procured from Sisco Research Laboratories Pvt. Ltd., Mumbai, India and Hi Media Research Laboratories Pvt. Ltd., Mumbai, India respectively. Olive oil was obtained from Figaro, Madrid, Spain. All the other chemicals used were of analytical grade

A known weight of fresh liver tissue was homogenized in 5 $\mathrm{ml}$ of $5 \%$ cold TCA and the homogenate was kept at $0-4^{\circ} \mathrm{C}$ for $30 \mathrm{~min}$. The precipitate obtained after centrifugation (10 min at $1000 \times \mathrm{g}$ ) was dissolved in $5 \mathrm{ml}$ of $5 \%$ cold TCA and left for $30 \mathrm{~min}$ at $0-4^{\circ} \mathrm{C}$. Thereafter, centrifugation (10 $\min$ at $1000 \times \mathrm{g}$ ) was carried out and the precipitate obtained was dissolved in alcohol: ether $(1: 3, \mathrm{v} / \mathrm{v})$ mixture and left for $30 \mathrm{~min}$ at $50^{\circ} \mathrm{C}$. This process was repeated once again. The contents were centrifuged at $1000 \times \mathrm{g}$ for $10 \mathrm{~min}$ and the supernatant was discarded. The lipid free pellet obtained was dissolved in $5 \mathrm{ml}$ of $0.1 \mathrm{~N} \mathrm{KOH}$ and incubated at $37^{\circ} \mathrm{C}$ for $16-18 \mathrm{~h}$. Then $0.17 \mathrm{ml}$ of $6 \mathrm{~N} \mathrm{HCl}$ and $5 \mathrm{ml}$ of $10 \%$ TCA were added to the incubated suspension and precipitate was allowed to be formed at $4^{\circ} \mathrm{C}$ for $30 \mathrm{~min}$. After centrifugation at $1000 \mathrm{x} g$ for $10 \mathrm{~min}$ the supernatant was separated and used for estimation of RNA. The pellet containing DNA and protein was heated at $90^{\circ} \mathrm{C}$ for $15 \mathrm{~min}$ after adding $5 \mathrm{ml}$ of 5\% TCA. The supernatant was then separated by centrifugation (10 $\mathrm{min}$ at $1000 \mathrm{x} \mathrm{g}$ ) after cooling at $4^{\circ} \mathrm{C}$ for $30 \mathrm{~min}$ and used for estimation of DNA.

\section{Deoxyribonucleic acid (DNA):}

The estimation of DNA in the liver was carried out by the method of Giles and Meyer (1965). The DNA in the supernatant reacts with diphenylamine to give a blue colored complex whose optical density was read at 620 $\mathrm{nm}$. The DNA content was expressed as $\mu$ moles/100 mg tissue weight ${ }^{4}$.

\section{Ribonucleic acid (RNA):}

The estimation of RNA in liver was carried out by the method of Schneider (1945). The RNA in the supernatant reacts with the orcinol reagent to give a greenish color, whose absorbance was read at $670 \mathrm{~nm}$. The concentration of RNA was expressed as $\mu$ moles $/ 100$ mg tissue weight ${ }^{10}$.

Table 1: Effect of diethanolamine on biochemical changes in liver of mice and its amelioration by curcumin

\begin{tabular}{|c|c|c|c|}
\hline \multicolumn{2}{|c|}{ Experimental groups } & DNA & \multicolumn{1}{c|}{ RNA } \\
\hline I & Untreated control & $601.10 \pm 2.73$ & $312.60 \pm 2.81$ \\
\hline II & Vehicle control & $599.60 \pm 1.92$ & $308.00 \pm 1.99$ \\
\hline III & Antidote control & $600.00 \pm 2.12$ & $313.90 \pm 1.26$ \\
\hline IV & DEA-LD & $503.11 \pm 2.90^{\mathrm{a}}(16.30)$ & $278.90 \pm 2.68^{\mathrm{a}}(10.78)$ \\
\hline V & DEA-MD & $399.18 \pm 2.60^{\mathrm{a}}(33.59)$ & $231.5 \pm 2.38^{\mathrm{a}}(25.94)$ \\
\hline VI & DEA-HD & $282.94 \pm 1.98^{\mathrm{a}}(52.92)$ & $179.9 \pm 1.01^{\mathrm{a}}(42.45)$ \\
\hline VII & DEA-HD+C10 & $346.70 \pm 2.60^{\mathrm{b}}(20.13)$ & $196.70 \pm 2.21^{\mathrm{b}}(13.11)$ \\
\hline VIII & DEA-HD+C20 & $501.30 \pm 2.20^{\mathrm{b}}(68.95)$ & $249.00 \pm 0.68^{\mathrm{b}}(53.94)$ \\
\hline IX & DEA-HD+C30 & $598.60 \pm 1.99^{\mathrm{b}}(99.68)$ & $300.10 \pm 1.44^{\mathrm{b}}(93.83)$ \\
\hline
\end{tabular}

Values are expressed as means \pm S.E.M.; $n=10$,

Level of significance: ${ }^{\mathrm{a}} \mathrm{p}<0.05$, as compared to untreated control (Group I)

${ }^{b} p<0.05$, as compared to toxin-treated groups (Group VI)

No significant difference was noted between untreated and vehicle control groups (Group I, II and III)

Values shown in parenthesis indicate:

Bold- Percent change in DEA-treated from untreated control

Italics- hepatoprotective index from DEA-HD

Units: DNA: $\mu$ moles/100 mg tissue weight; RNA: $\mu$ moles/100 mg tissue weight 


\section{RESULTS}

Table 1 shows effect of DEA on DNA and RNA contents and amelioration by curcumin. DEA was found to reduce DNA content of liver significantly $(p<0.05)$ and in dosedependent ( $r=0.9962)$ manner. No significant difference was noted between DNA content of different control groups, whereas LD, MD and HD of DEA (Group III, IV and V) reduced DNA content by $16.30 \%, 33.59 \%$ and $52.92 \%$ respectively.

Co-treatment of curcumin along with high dose of DEA was found to restore back DNA content. The hepatoprotective index calculated for DNA was (C10: $20.13 \%$, C20:68.95\% and C30 99.68\%.

Table 1 showed the reduction in RNA content of liver tissue upon DEA treatment. Different doses of DEA had significant $(p<0.05)$ reduction in RNA content as compared to untreated control. The effect was dose-dependent ( $r=$ 0.9833 ) and was highest with HD treatment (LD: $10.78 \%$, MD: $25.94 \%$ and HD: $42.45 \%)$.

Co-treatment with curcumin along with high dose of DEA showed increase in RNA content. The hepatoprotective index calculated for RNA was (C10: $13.11 \%$, C20: $53.94 \%$ and C30: 93.83\%) (Table 1).

\section{DISCUSSION}

Results showed that treatment of DEA for 30 days caused reduction in DNA and RNA contents in liver of mice (Table 1) Zeisel (2012) argued that this alterations might be due to choline deficiency as it is also linked with modifications to the DNA structure; DNA strands breaks, alterations of DNA methylation and gene expression. DNA and RNA are key molecular target for ROS. According to another study (Panchal and Verma in 2014) DEA significantly increases lipid peroxidation that could be the reason for reduction in protein, DNA and RNA contents.

It has been stated that curcumin helps protecting the liver from chronic-ethanol induced injury through attenuating oxidative stress through ERK/p38/Nrf2-mediated antioxidant signaling pathways ${ }^{9,15}$. That can be linked to present study which suggests curcumin ameliorates DEA induced reduction in nucleic acid content.

Co-treatment of curcumin along with high dose of DEA significantly $(p<0.05)$ increased DNA and RNA contents in liver of mice (Table 1). This could be due to free radical scavenging activity of curcumin by which it protects protein, DNA and RNA as curcumin exhibits enumerate antioxidant properties. In another study (Mathuria and Verma, 2007) stated that Curcumin treatment along with aflatoxin notably mitigates aflatoxin-induced changes in DNA, RNA and protein contents in the liver and kidney of mice. They also stated that amelioration in these contents might be due to increased DNA synthesis and reduction in harmful adduct formation. Several works have stated curcumin also increased protein content in caput and cauda epididymis of aflatoxin-treated mice ${ }^{11}$.
According to a study carried out by Hewlings and Kalman (2017) in developing countries it is estimated that $80 \%$ of individuals relay primarily on natural products for their healthcare needs. Plant based products are very effective and are relatively less toxic ${ }^{6}$. Curcumin is such an active compound that possess enormous antioxidant and health care properties. It has been argued that however, there is a noteworthy barrier towards the utilization of such plant based products in current healthcare because of stigmatization of these herbal remedies. Although the mechanisms of natural plant products and other plantbased drugs may not be well understood, it is essential to discover their mechanisms of action and effectiveness. This elaborated data will tend to widespread acceptance of these alternative forms of treatment and allow it to be used in modern medicine ${ }^{5}$.

Cheng et al., (2003) investigated the inhibitory effects of curcumin, garlic squeeze, grape seed extract, tea polyphenols, vitamin $\mathrm{E}$ and vitamin $\mathrm{C}$ on nicotine-DNA adduction in vivo. They suggested that these dietary constituents are beneficial to prevent the harmful adduct formation and thus to block the potential toxicological consequences $^{3}$. The results reported by Cheng and colleagues provides support to the present finding that suggests potent mitigatory effects of curcumin.

\section{CONCLUSION}

The present investigation and its results conclude that orally administered of high dose of diethanolamine contributes to reduction in nucleic acid content in liver tissues. Such conditions can be mitigated by the use of potent antioxidant curcumin which reduces the risk of reduction in nucleic acid content in dose-dependent manner.

Acknowledgement: The authors are grateful to the University Grants Commission (UGC), (RGNF) New Delhi for Financial assistance. We are also indebted to the Department of zoology, school of Sciences, Gujarat University, India, for providing the space and facilities to complete the above Research work. The authors are grateful in this regard.

\section{REFERENCES}

1. Anon. Final report on the safety assessment of triethanolamine, diethanolamine and monoethanolamine. Journal of the American College of Toxicologyl, 1983;2:183235.

2. Bremmer HJ, Prud'homme de Lodder LCH and Engelen, JGM. Cosmetics Fact Sheet: To assess the risks for the consumer Updated version for consumer exposure 4. Report No. RIVM 320104001/2006. 1-77.

3. Cheng Y, Li HL, Wang HF, Sun HF, Liu YF, Peng SX, Liu KX, Guo $\mathrm{ZY}$. Inhibition of nicotine-DNA adduct formation in mice by six dietary constituents. Food and chemical toxicology. $2003 \mathrm{Jul}$ 1;41(7):1045-50.

4. Giles KW, Myers A. An improved diphenylamine method for the estimation of deoxyribonucleic acid. Nature. 1965 Apr;206(4979):93. 
5. Goel A, Kunnumakkara AB, Aggarwal BB. Curcumin as "Curecumin": from kitchen to clinic. Biochemical pharmacology. 2008 Feb 15;75(4):787-809.

6. Hewlings SJ, Kalman DS. Curcumin: a review of its effects on human health. Foods. 2017 Oct;6(10):92.

7. Kocaadam B, Şanlier N. Curcumin, an active component of turmeric (Curcuma longa), and its effects on health. Critical reviews in food science and nutrition. 2017 Sep 2;57(13):2889-95.

8. Mathuria NE, Verma RJ. Ameliorative effect of curcumin on aflatoxin-induced toxicity in DNA, RNA and protein in liver and kidney of mice. Acta Pol Pharm. 2007 Nov 1;64:497-502.

9. Panchal S. Evaluation of diethanolamine induced reproductive toxicity in male rodent and its amelioration. Department of Zoology, Gujarat University, Sept-2014.
10. Schneider WC. Phosphorus compounds in animal tissues: I. Extraction and estimation of desoxypentose nucleic acid and of pentose nucleic acid. Journal of Biological Chemistry. 1945 Nov 1;161(1):293-303.

11. Verma RJ, Mathuria N. Effect of curcumin on aflatoxininduced biochemical changes in testis of mice. Fertility and sterility. 2009 Feb 1;91(2):597-601.

12. Xiong ZE, Dong WG, Wang BY, Tong QY, Li ZY. Curcumin attenuates chronic ethanol-induced liver injury by inhibition of oxidative stress via mitogen-activated protein kinase/nuclear factor E2-related factor 2 pathway in mice. Pharmacognosy magazine. 2015 Oct;11(44):707.

13. Zeisel SH. Dietary choline deficiency causes DNA strand breaks and alters epigenetic marks on DNA and histones. Mutation Research/Fundamental and Molecular Mechanisms of Mutagenesis. 2012 May 1;733(1-2):34-8.

Source of Support: The author(s) received no financial support for the research, authorship, and/or publication of this article. Conflict of Interest: The author(s) declared no potential conflicts of interest with respect to the research, authorship, and/or publication of this article.

For any question relates to this article, please reach us at: editor@globalresearchonline.net New manuscripts for publication can be submitted at: submit@globalresearchonline.net and submit_ijpsrr@rediffmail.com 